FACTA UNIVERSITATIS

Series: Physical Education and Sport, Vol. 16, No 2, 2018, pp. 387 - 397

https://doi.org/10.22190/FUPES180907035G

Research article

\title{
THE RELATIONS BETWEEN BODY COMPOSITION AND SPECIFIC FITNESS ABILITIES OF MEMBERS OF THE SPECIAL BRIGADE OF THE SERBIAN ARMED FORCES
}

\author{
UDC 796.012.1:611:356.35
}

\author{
Mihajlo Golubović, Saša Pantelić, Saša Veličković
}

Faculty of Sport and Physical Education, University of Niš, Niš, Serbia

\begin{abstract}
The research was carried out on a sample consisting of the members of the Special Brigade of the Serbian Armed Forces, members of the $63^{\text {rd }}$ Parachute Battalion. A

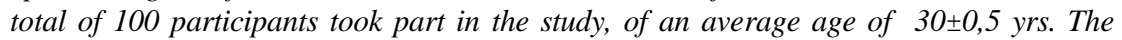
subject matter of this paper are their body composition and specific fitness abilities. The aim of the paper was to determine the correlation between body composition and specific fitness abilities, as well as to determine the cross-correlation between the parameters of body composition and specific fitness abilities. A canonical correlation analysis was used to determine the connection between the set of predictor variables and the criterion variable. Based on the obtained results it could be concluded that there is a significant correlation $(p=.010)$ between body composition and fitness abilities. It can be concluded that the excess of fat tissue (BF\%, BFkg, index visceral $B F)$ and BMI have a negative effect on fitness, while a greater amount of muscle mass (MM\% and MMkg) has a positive influence on fitness. The results indicate that participants who do not have as many layers of fat have better values for repetitive power of the abdominal muscles, and that the percentage of muscle mass has a positive effect on the repetitive power of the pectoral muscles, muscles of the arms and abdomen.
\end{abstract}

Key words: Body composition, specific fitness abilities, armed forces

\section{INTRODUCTION}

Current research has indicated that achieving top results in sport in addition to the training process also to some extent depends on individual elements of body composition. They have an especially great influence on basketball players, volleyball players, put shot

Received September 7, 2018 / Accepted October 25, 2018

Corresponding author: Saša Pantelić

University of Niš, Faculty of Sport and Physical Education, Čarnojevića 10a, 18000 Niš, Serbia

Phone: +381 $18510900 \cdot$ E-mail: spantelic2002@yahoo.com 
throwers, long distance runners, and athletes involved in other types of sport and sport disciplines (Milanović, Jokić, \& Šimek, 2006).

Each functional-diagnostic procedure begins with morphological anthropometry. One of the tasks of anthropometry, among other things, is to guide athletes toward sport disciplines in which they might be expected to achieve optimal results, based on individual anthropometric dimensions.

Body composition includes an evaluation of the prevalence of subcutaneous fat tissue and evaluation of muscle and skeletal mass in the human body. The percentage of body fat is the main parameter in diagnosing body composition and obesity (Mišigoj-Duraković et al., 1999). Body composition according to the American Alliance for Health, Physical Education, Recreation and Dance (AAHPERD, 1989) represents the ratio between the fat, muscle and bone tissue in the overall body mass. Body composition is represented by the size and grouping of existing measurable segments of its components (Ugarković, 2001). Corrections made to body composition are often equated with a decrease in body weight, but this is an incorrect interpretation. A decrease in body weight does not mean a simultaneous decrease in the percentage of body fat, since it could also be caused by a reduction in the muscle tissue (Cvetković, 2007).

It is well-known that a low percentage of body fat in the overall body structure is desirable in many sports both from the aspect of esthetics and the creation of the so-called "athletic composition" in sports such as "bodybuilding" or athletic gymnastics, but also in sports that included movement is opposed to gravity, e.g., in running or jumping (Dowson, Cronin, \& Presland, 1999; Reilly, Bangsbo \& Franks, 2000). On the other hand, muscle mass improves sport achievements in activities which require muscle power and endurance but also in those which require a particular aerobic ability (Ramadan \& Byrd, 1987; Green, 1992; Rico-Sanz, 1998). Athletes have less fat in their body structure compared to inactive individuals, and the lowest values are found in endurance sports, e.g., triathlon, marathon, cross-country skiing, cycling (Heyward \& Stolarczyk, 1996). Muscle mass is also greater among athletes and among men, where it usually exceeds 55 and even $60 \%$ of the overall body mass (Martin, Spenst, Drinkwater, \& Clarys, 1990). In addition, the density of the nonfat body mass of physically active individuals is greater than that of sedentary individuals with a greater mineral and bone density and muscle mass of athletes (Heyward \& Stolarczyk, 1996).

Determining motor skills and anthropological characteristics and their influence on certain indictors of physical abilities is a current problem not only in sport practice, but also in professions which require a high level of physical ability required. A high level of physical abilities is especially for the members of the Special Brigade. A high level of physical ability to a great extent influences success in performing many tasks, and thus an increase in the readiness of the unit. In order to determine the state of the physical abilities of professional military servicemen, and the uniform evaluation and estimation of physical abilities, a battery of tests is used. The battery of tests used to evaluate physical abilities evaluate repetitive endurance of power of the arms, shoulder belt, pectoral muscles and torso, aerobic endurance and leg muscle endurance, aerobic-anaerobic endurance in an aquatic environment, aerobic capacity, as well as general physical ability and movement coordination.

When it comes to relation between motor skills and body structure, it was determined that the participants with the lowest motor skills have the most fat tissue and the greatest 
waist volume, while the participants with the best results have a significantly less fat tissue and a smaller waist volume (Glavač, 2015). Research papers published worldwide confirm that the current problem of obesity is also being analyzed in military structures (Mullie, Vansant, Hulens, Clarys, \& Degrave, 2008; Heinrich et al., 2008). Even when selecting recruits and potential cadets, as well as during training, an analysis of morphological status tells us that the problem with overweight and excess body fat is quite prevalent (Crawford et al., 2011). Kyrolainen et al. (2008) offer an overview of the morphological and functional characteristics of Finnish soldiers in relation to the number of days they spent on sick leave. Based on the results, the authors cite that, in general, Finnish soldiers are in good shape, but with significant individual differences between them. They point out that insufficient muscle functionality, aerobic abilities and BMI, are risk factors for possible absence from work due to illness, which is costly for society as a whole, but also for the individual. Authors link the attitude toward physical activity with possible health issues. They cite that people who exercise three times a week at high intensity spend fewer days on sick leave than those who do not train regularly.

Spartali, Kostantinos, Ioannis, \& Thrasivoulos (2014) studied BMI and the fat component as the predictors of physical ability among cadets of the Greek military academy. The aim of this study was twofold: first to measure the body mass index (BMI) and percentage of body fat $(\% \mathrm{BF})$ with the aim of monitoring the cadets of the Greek military academy, and second, to evaluate the aspects of improving the performance of cadets in certain physical activities, so as to help them be more efficient in their duties as officers. The study included 868 cadets with an average age of 19.9. It was indicated that 26 cadets, who belonged to the groups with a lower $\mathrm{BMI}$ and $\mathrm{BF} \%$, had an advantage during the testing. The percentage of the body fat component $(\% \mathrm{BF})$ was presented as a better predictor than BMI in fulfilling tasks related to tests of motor skills. In the conclusion it was recommended that several anthropometric variables for the classification of cadets be used, that is, if they did not depend exclusively on the value of the BMI, they would have a holistic image of their morphological status and physical abilities.

Crawford et al. (2011) in their work compare the functional abilities of professional servicemen divided into two groups. The first group had a fat body mass less than $18 \%$, and the other greater than $18 \%$. The authors point out that the military increases its numbers by enlisting civilians, which $68 \%$ of the time belong to the group of overweight and obese individuals. The supervising health center for the military, AFHSC, published the findings that the number of overweight and obese increased from 1998 to 2008 from 25000 to 70000 . The results have indicated that soldiers with the same amount of fat free mass (FFM), but with a smaller percentage of fat have better results on tests of aerobic and anaerobic abilities, as well as on strength tests. For the studied sample, it was determined that the correlation between $\mathrm{BF} \%$ and $\mathrm{VO} 2$ max is high negative, with a value of -0.63 . The authors point out that in addition to reduced physical abilities as measuring indictors in the military, the consequences which stem from overweight and obesity should also be taken into consideration. Due to an increase in the fat component, man is more susceptible to injuries of the muscle-skeletal system, which leads to a decrease in strength and the decreased professional-work ability of a soldier. Future studies should be based on finding a connection between practical activities characteristic for servicemen and body composition, such as tactical abilities and combat activity. 
The aim of the paper was to determine the correlation between body composition and specific fitness abilities, as well as to indicate the cross-correlation between the parameters of body composition and specific fitness abilities.

\section{METHODS}

\section{Sample of participants}

The research was carried out on a sample of the members of the Special Brigade of the Serbian Armed Forces, members of the $63^{\text {rd }}$ Parachute Battalion. In total 100 participants took part in the study, with an average age of $30 \pm 0,5$ years. The participants included in this sample belong to the group of a physically active population. As part of their physical training, they exercise every day for a period of 90 minutes. All of the participants were in good health during the study. Their average body height was $180.82 \mathrm{~cm}$, and average body mass was $83.39 \mathrm{~kg}$.

\section{Sample of measuring instruments}

Two groups of measuring instruments were used in the study: the first, the predictor group, consisted of six parameters for the evaluation of body composition, and the second, the criterion group, consisted of five motor tests for the evaluation of specific fitness abilities.

To evaluate body composition, we used the bioelectric impedance analysis (an analysis of measuring electric conductivity - Bioelectrical Impedance Analysis - BIA). The measurements were realized using the "Omron BF511" device. The predictor group of measuring instruments for the evaluation of body compositions were:

- Body fat (expressed in \%);

- Overall layers of body fat (expressed in $\mathrm{kg}$ );

- Visceral adiposity index;

- Body mass index-BMI;

- Muscle mass (expressed in \%);

- Overall body muscle mass (expressed in $\mathrm{kg}$ ).

To evaluate the specific fitness abilities we used five tests, as prescribed by the standard for evaluating the physical abilities of members of the Special Brigade of the Serbian Armed Forces (Uputstvo za fizičku obuku u Vojsci Srbije, 2011). The criterion group variables for the evaluation of fitness abilities included:

- Push-ups for 2 min (repetitive power of the arms, shoulder belt and pectoral muscles expressed as number of repetitions);

- Torso body lifts for 2 min (repetitive power of the torso muscles expressed as number of repetitions);

- 3200 m run (aerobic endurance expressed in s);

- Infantry training obstacle course (general physical fitness and movement coordination expressed in s);

- Rope climbing, 7 meters (explosive power of the back, shoulder and arm muscles expressed in s). 


\section{Statistical analysis}

For all the variables (predictor and criterion) the basic descriptive parameters were calculated: Mean, Standard Deviation (Std.Dev), Minimum (Min) and Maximum (Max) results, and Range. To determine the connection between the set of variables we applied a Canonical Correlation Analysis. The data were processed using the statistical package Statistica 7.0.

\section{RESULTS}

Analyzing the fitness abilities of the participants based on the means of the tests Pushups for $2 \min$ (69.70) and Torso body lifts for $2 \min$ (83.74), it can be concluded that the repetitive power of the participants is at a very high level.

Based on the means of the percentage of layers of body fat (20.94), the visceral adiposity index (7.54), body mass index (25.36) and percentage of body muscle mass (38.23), following the recommendations for the values of body composition of the World Health Organization (WHO), we can conclude that these are participants with ideal body composition.

Table 1 Basic descriptive statistics for the evaluation of the relation between body composition and specific fitness abilities $(n=100)$

\begin{tabular}{lrrrrr}
\hline Variable & Mean & Std.Dev. & Min & Max & Range \\
\hline Body Fat (in \%) & 20.94 & 4.61 & 7.30 & 29.6 & 22.30 \\
Body Fat (in kg) & 17.62 & 4.83 & 5.30 & 29.2 & 23.90 \\
Visceral Adiposity Index & 7.54 & 3.15 & 3.00 & 27.6 & 24.60 \\
BMI & 25.36 & 2.66 & 10.00 & 32.7 & 22.70 \\
Muscle mass (in \%) & 38.23 & 2.79 & 32.20 & 45.0 & 12.80 \\
Muscle mass (in kg) & 31.79 & 2.94 & 23.22 & 38.6 & 15.36 \\
Push-ups for 2 min (in reps.) & 69.70 & 8.61 & 45.00 & 100.0 & 55.00 \\
Torso body lifts for 2 min (in reps.) & 83.74 & 11.86 & 35.00 & 118.0 & 83.00 \\
3200 m run (in s) & 831.01 & 83.25 & 632.00 & 1096.0 & 464.00 \\
Infantry training obstacle course (in s) & 139.02 & 15.36 & 99.00 & 183.0 & 84.00 \\
Rope climbing, 7 meters (in s) & 10.70 & 2.51 & 7.00 & 19.6 & 12.60 \\
\hline
\end{tabular}

Table 2 shows the cross-correlations between the analyzed parameters of body composition and the motor variables. Based on the values, we can note that between the percentage of layers of body fat and torso body lifts for 2 min there is a low negative correlation (-.29). A further analysis of the results indicates low negative correlations between the variable of the percentage of layers of body fat and the $3200 \mathrm{~m}$ run (.29), the infantry training obstacle course a (.29), as well as rope climbing, $7 \mathrm{~m}(.32)$.

Based on the shown values, a low negative correlation was noted between the Overall layers of fat in kilograms and Rope climbing, $7 \mathrm{~m}$ (.33), as well as the $3200 \mathrm{~m}$ run (.32) and Torso body lifts for 2 min (-.31).

Studying the correlations between the Visceral adiposity index and motor skills, we can note that there is a low negative correlation with success on the Infantry training obstacle course (.33), the $3200 \mathrm{~m}$ run (.30), as well as Rope climbing, $7 \mathrm{~m}(.28)$. Also, there is a low negative correlation with the Torso body lifts for $2 \mathrm{~min}(-.27)$. 
Table 2 The matrix of cross-correlation of the parameters of body composition and specific fitness abilities

\begin{tabular}{lccccc}
\hline & $\begin{array}{c}\text { Push-ups } \\
\text { for 2 min }\end{array}$ & $\begin{array}{c}\text { Torso body } \\
\text { lifts for 2 min }\end{array}$ & Running & $\begin{array}{c}\text { Infantry training } \\
\text { obstacle course }\end{array}$ & $\begin{array}{c}\text { Rope climbing, } \\
7 \mathrm{~m}\end{array}$ \\
\hline Body Fat (in \%) & -.20 & -.29 & .29 & .29 & .32 \\
Body Fat (in kg) & -.18 & -.31 & .32 & .27 & .33 \\
Visceral Adiposity Index & -.15 & -.27 & .30 & .33 & .28 \\
BMI & .05 & -.13 & .22 & .08 & .13 \\
Muscle mass (in \%) & .21 & .28 & -.27 & -.31 & -.33 \\
Muscle mass (in kg) & .12 & -.00 & .03 & -.16 & -.03 \\
\hline
\end{tabular}

Of the correlations between BMI with motor skills, the greatest one is a low correlation with the $3200 \mathrm{~m}$ run $(.22)$.

By further analyzing Table 2, we can note low positive correlations between the Percentage of muscle mass and Rope climbing, $7 \mathrm{~m}$ (-.33), the Infantry training obstacle course (-.31), Torso body lifts for $2 \mathrm{~min}(.28)$, as well as the $3200 \mathrm{~m}$ run $(-.27)$.

Finally, based on the obtained values, we can conclude that there is a small connection between the Overall body muscle mass in kilograms and specific fitness abilities, which is indicated by the fact the greatest noted correlation is with the Infantry training obstacle course (-.16).

By applying the canonical correlation analysis, we determined a connection between the predictor and criterion group of variables.

Table 3 Isolated canonical functions

\begin{tabular}{rllccc}
\hline & $\mathrm{R}$ & $\mathrm{R}^{2}$ & Chi-sqr. & $\mathrm{df}$ & $\mathrm{p}$ \\
\hline $\mathbf{0}$ & $\mathbf{5 1}$ & $\mathbf{. 2 6}$ & $\mathbf{5 0 . 9 8}$ & $\mathbf{3 0}$ & $\mathbf{. 0 1 0}$ \\
1 & .38 & .14 & 23.42 & 20 & .269 \\
2 & .26 & .07 & 9.22 & 12 & .684 \\
3 & .17 & .03 & 2.84 & 6 & .828 \\
4 & .04 & .00 & 0.16 & 2 & .922 \\
\hline \multicolumn{5}{r}{ Legend: R - canonical correlation coefficient; $\mathrm{R}^{2}-$ the coefficient of determination for a } \\
\multicolumn{5}{c}{ pair of canonical factors; Chi-Sqr.- Bartlett's Chi-Square test; df - degrees of freedom; } \\
\end{tabular}

By analyzing the results in Table 3, and based on the values of the correlation coefficients, we can determine that they are mutually connected to one pair of statistically significant canonical factors at the .05 level of significance. This pair of canonical factors explains $26 \%(\mathrm{R} 2=.26)$ of the variance.

To explain the structure of the canonical dimensions, we defined the structures of isolated canonical factors in the studied space of body composition and specific fitness abilities.

By analyzing the factor structure of body composition (Table 4), it can be concluded that the first isolated canonical factor with the greatest projection with a positive sign can be found for the visceral adiposity index (.75), the overall layers of body fat in kilograms (.68), percentage of body fat (.65) and the body mass index (.40). The significant correlation coefficients with a negative sign can be found for the percentage of muscle 
mass (-.66), while the projections of the overall body muscle mass in kilograms on the first isolated canonical factor were not statistically significant (-.13).

Table 4 The factor structure of body composition and specific fitness abilities

\begin{tabular}{lclc}
\hline & Root 1 & & Root 1 \\
\hline Body Fat (in \%) & .65 & Push-ups for 2 min (in reps.) & -.37 \\
Body Fat (in kg) & .68 & Torso body lifts for 2 min (in reps.) & -.61 \\
Visceral Adiposity Index & .75 & 3200 m run (in s) & .71 \\
BMI & .40 & Infantry training obstacle course (in s) & .92 \\
Muscle mass (in \%) & -.66 & Rope climbing, 7 meters (in s) & .68 \\
Muscle mass (in kg) & -.13 & & \\
\hline
\end{tabular}

For the isolated canonical factor of specific fitness abilities, the greatest projections with a positive sign were determined for the Infantry training obstacle course (.92), the $3200 \mathrm{~m}$ run (.71) and Rope climbing, $7 \mathrm{~m}$ (.68). Significant correlation coefficients with a negative sign were determined for the Push-ups for $2 \mathrm{~min}(-.37)$ and Torso body lifts for 2 $\min (-.61)$.

\section{DISCUSSION}

By analyzing the results in Table 1, which shows the values of body composition, it can be concluded that among the participants the percentage of body fat is 20.94 .

By comparing these results with the recommended values for the percentage of body fat according to various authors (Brozek, 1952., as cited in De Vris, 1976; Nedeljković, Kanjuh, \& Vukotić, 1994; Ostojić, Mazić, \& Dikić, 2003; Dikić \& Živanić, 2003; Ugarković, 2001; Medved, 1987; Gallagher et al., 2000; Tharp \& Woodman, 2002; Deurenberg, Yap, \& Van Staveren, 1998; ACSM, 2006), it can be concluded that the measured numeric values are on the upper limit of the recommended values (10\%-20\%).

The percentage of muscle mass is 38.23 . The recommended values for this variable are 40\% for younger individuals (Medved, 1987; Gallagher \& Song, 2003; Ostojić et al., 2003; Ugarković, 2001), while for the elderly these values are reduced by approximately $30 \%$ (Forbes, 1987). The percentage of muscle mass is within the recommended limits, and the obtained values are likely the consequence of continued physical exercise, as well as a proper diet.

The average values of BMI are 25.36. The obtained values are on the very limit of normal weight (18.5-24.9) and level I obesity (25.0-29.9) of the recommended values (World Health Organization, 1997; Gallagher, \& Song, 2003; Ostojić et al., 2003; Dikić \& Živanić, 2003; National Heart and Lung Institute, 1998). The obtained values indicate that a reduction in body mass of the participants, which are on the upper level of the recommended values, improved the values of BMI, and thus the values of the percentage of the muscle mass. Based on the results in Table 1, which show the values of the motor skills, it can be concluded that the fitness abilities of the participants are at a satisfactory level. The average result of the Push-ups for 2 min (69.7 reps) are on the upper limit of the recommended values (50-73 reps) for this particular category (Uputstvo za fizičku obuku u Vojsci Srbije, 2011). In addition, the average values for Torso body lifts for 
$2 \mathrm{~min}$ ( 83.74 reps) are on the upper limits of the recommended values (65-88 reps). The data obtained for the $3200 \mathrm{~m}$ run $(831.01 \mathrm{~s})$ are within the limits of the recommended values (750-900 s), as is the average result for the Infantry training obstacle course $(139.02 \mathrm{~s})$ based on the recommended values $(115-160 \mathrm{~s})$. The average results for Rope climbing, $7 \mathrm{~m}(10.70 \mathrm{~s})$ are on the lower level of the recommended values (7.00-12.00 s).

All this indicates that the repetitive power of the participants is on a high level. On the other hand, aerobic endurance of the participants satisfied the evaluation criteria, but is slightly lower than repetitive power. A note should be made of the fact that the results for the Infantry training obstacle course and Rope climbing, in addition to strength and aerobic-anaerobic endurance, are also significantly affected by technique, which might indicate that this factor had a significant impact on the results among certain participants.

based on the results shown in Table 2, we can conclude that the excess of body fat ( $\%$ and $\mathrm{kg}$, visceral adiposity index BF) and BMI have a negative impact on fitness abilities, while large amounts of muscle mass (\% and $\mathrm{kg}$ ) have a positive effect on fitness abilities.

The research results indicate that there are significant findings regarding the correlation between body composition and fitness abilities. As assumed, and based on the existing research (Milanović et al., 2006), certain correlations have been confirmed. By analyzing the results for the connection between the set of predictor and criterion measuring instruments, a statistical significance can be noted.

The results obtained through measuring indicate that certain variables are significantly related, both in case of body composition and specific fitness abilities.

If we were to evaluate the measured sample, and based on insight into the basic parameters of distribution, the homogeneity of the sample would be determined, along with a high level of repetitive power of the participants, as well as the fact that these participants have an ideal body composition

By analyzing the results of the measurements, we could conclude that the overall amount of internal (visceral) fat tissue cannot significantly change the body mass index, since its weight is negligible compared to the overall body weight of the participants. However, it is clear that an increase in the visceral (internal) adiposity index increases the overall amount of fat. This study has shown that the increase in the percentage of body fat is accompanied by a decrease in the percentage of muscle mass, and vice versa.

Also, the results of the measurements confirm that BMI is a height - weight indicator which does not reflect body composition. In addition, BMI as an indicator of success at a physical evaluation, can only be taken into consideration when we are measuring aerobic endurance, which has also been indicated by existing research (Đurašković, Nikolić, Pantelić, Veličković, \& Bojić, 2011).

Based on the presented results, it could be concluded that there are significant correlations among specific fitness abilities.

It can be determined that the repetitive power of the pectoral muscles and arms is connected to other forms of power. The presented results indicate a high connection between repetitive power of the pectoral muscles, arms and the abdomen. The measurements indicated that greater aerobic endurance improves the results for the Infantry training obstacle course and Rope climbing, which has been confirmed by Mullins (2012).

It should be noted that the results for the Infantry training obstacle course and Rope climbing, are in addition to strength and anaerobic endurance, significantly influenced by technique, which could indicate that this factor had a significant impact on the results 
among certain participants. On the other hand, when studying disciplines such as Infantry training obstacle course and Rope climbing, the measurements indicated that an improvement in the results in one discipline improves the results in another.

This research indicates that the overall body muscle mass in kilograms has a negative effect on the repetitive power of the arms and pectoral muscles. It was proven that an increase in the overall body muscle mass in kilograms to a small extent reduced the repetitive power of the abdomen. In addition to that, the percentage of body fat has a negative effect on aerobic endurance, but not to a great extent (Dowson et al., 1999; Reilly et al., 2000).

The research results indicate that the percentage of muscle mass to a small extent has a positive effect on the repetitive power of the pectoral muscles, arms and abdomen. Also, an increase in muscle mass to a small extent increases the results in the declines of the $3200 \mathrm{~m}$ run, the Infantry training obstacle course, and Rope climbing, 7m (Ramadan \& Byrd, 1987; Green, 1992; Rico-Sanz, 1998; Glavač, 2015).

\section{CONCLUSION}

The aim of this study was to determine the correlation between body composition and specific fitness abilities. In total, 100 participants took part in the research, average age $30 \pm 0.5$ years. Two groups of measuring instruments were used: first the predictor group, which consisted of six morphological measurements, and the second the criterion one, which consisted of five motor tests for the evaluation of specific fitness abilities.

To determine the connection between the set of predictor and criterion measuring instruments, a canonical correlation analysis was used. The results of the canonical correlation analysis have indicated that there are significant correlations between certain values of body composition and specific fitness abilities. As the most significant, we identify the following:

- a negative correlation (-.31) between the overall layers of body fat in kilograms and Torso body lifts for $2 \mathrm{~min}$, which indicates that an increase in the overall layers of body fat in kilograms decreases the repetitive power of the abdomen;

- a positive correlation (.32) between the overall layers of body fat in kilograms and the $3200 \mathrm{~m}$ run, which indicates that the amount of body fat is significant for aerobic endurance;

- a positive correlation between the percentage of muscle mass and Push-ups for 2 $\min (.21)$ and Torso body lifts for $2 \mathrm{~min}(.28)$, which indicates that the percentage of the muscle mass has a positive effect on the repetitive power of the pectoral muscles, arms and abdomen.

The questions of if, and to which extent, the results for certain specific fitness abilities influence other variables, such as speed, technique, coordination, flexibility and the like, leave room for further studies on this topic 


\section{REFERENCES}

AAHPERD-American Alliance for Health, Physical Education, Recreation and Dance (1989). Physical bestthe AAHPERD guide to physical fitness education and assessment. Reston: American Alliance for Health, Physical Education, Recreation and Dance.

ACSM-American College of Sports Medicine (2006). Resource manual for guidelines for exercise testing and prescription, 5th Edition. Baltimore: Lippincott Williams and Wilkins.

Crawford, K., Fleishmati, K., Abt, P.J., Sell, C.T., Lovalekar, M., Nagai, T., et al. (2011). Less body fat improves physical and physiological performance in army soldiers. Military Medicine, 176 (1), 35-43.

Cvetković, M. (2007). Efekti različitih programa aerobika kod studenata fakulteta sporta i fizičkog vaspitanja (The effects of various aerobic programs in students of faculties of sport and physical education). Doctoral dissertation. Novi Sad: Faculty of Sport and Physical Education, University of Novi Sad. In Serbian

De Vris, H.A. (1976). Fiziologija fizičkih napora u sportu i fizičkom vaspitanju (Physiology of physical efforts in sport and physical education). Belgrade: Partizan. In Serbian

Deurenberg, P., Yap, M., \& Van Staveren, W. (1998). Body mass index and percent body fat: a meta-analysis among different ethnic groups. International Journal of Obesity, (22), 11641171.

Dikić, N., \& Živanić, S. (2003). Osnove monitoringa srčane frekvencije u sportu i rekreaciji (Fundamentals of heart rate monitoring in sports and recreation). Belgrade: Sports Medicine Association of Serbia. In Serbian

Dowson, M.N., Cronin, J.B., \& Presland, J.D. (1999) Anthropometric and physiological differences between groups of New Zealand national soccer players based on sex and age. Journal of Sports Sciences, 17, 810-811.

Đurašković, R., Nikolić, M., Pantelić, S., Veličković, S., \& Bojić, I. (2011). Weight-height relations of the elite athletes in different sports disciplines. Glasnik Antropološkog društva Srbije, (46), 25-32.

Forbes, G.B. (1987). Body composition in infancy, childhood, and adolescence. In Human Body Composition, (pp. 125-155). New York: Springer-Verlag

Gallagher, D, \& Song, MY. (2003). Evaluation of body composition: practical guidelines. Primary Care, 30(2), 249-265

Gallagher, D., Heymsfield, S.B., Heo, M., Jebb, S.A., Murgatroyd, P.R., \& Sakamoto, Y. (2000). Healthy percentage body fat ranges: an approach for developing guidelines based on body mass index. The American Journal of Clinical Nutrition, 72(3), 694-701.

Glavač, B.T. (2015). Motoričke sposobnosti, morfološki status i životne navike kod pripadnika Vojske Srbije (Motor skills, morphological status and life habits of members of the Serbian Armed Forces). Doctoral dissertation. Belgrade: Faculty of Sport and Physical Education, University of Belgrade. In Serbian

Green, S. (1992). Anthropometric and physiological characteristics of south Australian soccer players. Australian Journal of Science and Medicine in Sport, 24, 3-7.

Heinrich, M.K., Jitnarin, N., Suminski, R.R., Berkel, L.V., Hunter, M.C., Alvarez, L, et al. (2008). Obesity classification in military personnel: A comparison of body fat, waist circumference, and body mass index measurements. Military Medicine, 173(1), 67-73.

Heyward, V., \& Stolarczyk, H. (1996). Applied body composition assessment. Human Kinetics: Champaign.

Kyrolainen, H., Hakkinen, K., Kautiainen, H., Santtila M., Pihlainen, K., \& Hakkinen, A. (2008). Physical fitnes, BMI and sickness absence in male military personel. Occupational Medicine, 58, 251-256.

Martin, A.D., Spenst, L.F., Drinkwater, D.T., \& Clarys, J.P. (1990) Anthropometric estimates of muscle mass in man. Medicine and Science in Sports and Exercise, 22, 729-733.

Medved, R. (1987). Sportska medicina (Sports medicine). Zagreb: Jugoslovenska medicinska naklada. In Croatian

Milanović, D., Jokić, I., \& Šimek, S. (2006). Osnove sporta i sportskog treninga (The basics of sports and sports training). In: S. Hajmer \& R. Čajavec (Ed) Sportska medicina (Medicine of Sport) (pp. 46-58). Zagreb: Faculty of Kinesiology, University of Zagreb. In Croatian

Mišigoj-Duraković, M., Duraković, Z., Findak, V., Hajmer, S., Horga, S., Latin, V., et al. (1999). Tjelesno vježbanje i zdravlje (Physical exercise and health). Zagreb: Grafos \& Faculty of Physical Culture, University of Zagreb. In Croatian

Mullie, P., Vansant, G. Hulens, M., Clarys, P., \& Degrave, E. (2008). Evaluation of body fat estimated from body mass index and impedance in belgian male military candidates: Comparing two methods for estimating body composition. Military Medicine, 173(3), 266-70.

Mullins, N. (2012). Obstacle course challenges: history, popularity, performance demands, effective training, and course design. Journal of Exercise Physiology Online, 15(2). 
Nedeljković, S., Kanjuh, V., \& Vukotić, M. (1994). Kardiologija (Cardiology). Belgrade: Zavod za izdavačku delatnost, Belgrade. In Serbian

National Heart and Lung Institute (1998). Clinical guidelines on the identification, evaluation, and treatment of overweight and obesity in adults. US Dept of Health, Education and Welfare.

Ostojić, S., Mazić, S., \& Dikić, N. (2003). Telesne masti i zdravlje (Body fat and health). Belgrade: Sports Medicine Association of Serbia. In Serbian

Ramadan, J., \& Byrd, R. (1987). Physical characteristics of elite soccer players. Journal of Sports Medicine and Physical Fitness, 27, 424-428.

Reilly, T., Bangsbo, J., \& Franks, A. (2000). Anthropometric and physiological predispositions for elite soccer. Journal of Sports Sciences, 18, 669-683.

Rico-Sanz, J. (1998) Body composition and nutritional assessments in soccer. International Journal of Sport Nutrition, 8, 113-123.

Spartali, I., Kostantinos, H., Ioannis, K. \& Thrasivoulos, P. (2014). Body fat percentage and body mass index as predictors of cadets' physical performance. The Open Sports Sciences Journal, 7(Suppl-1, M9), 53-59.

Tharp, G.D., \& Woodman, D.A. (2002). Experiments in physiology (8th edition). NY: Prentice Hall.

Ugarković, D. (2001). Osnovi sportske medicine (Basics of sports medicine). Belgrade: College for sports trainers. In Serbian

Uputstvo za fizičku obuku u Vojsci Srbije (Guidelines for the physical training of the Serbian Armed Forces) (2011). Training and Doctrine Department, Belgrade: The General Staff of the Serbian Armed Forces. In Serbian

World Health Organization (1997). Obesity-Preventing and managing the global epidemic Report of WHO consultations on obesity, 7-17. Geneva, Switzerland

\section{ODNOS IZMEĐU SASTAVA TELA I SPECIFIČNIH FIZIČKIH SPOSOBNOSTI KOD ČLANOVA SPECIJALNE BRIGADE VOJSKE SRBIJE}

Istraživanje je sprovedeno na uzorku pripadnika Specijalne brigade Vojske Srbije, pripadnika 63. bataljona padobranstva. U istraživanju je učestvovalo ukupno 100 ispitanika, sa prosečnom

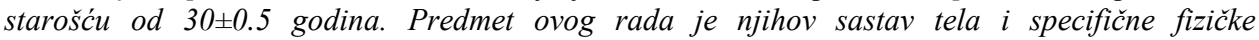
sposobnosti. Cilj rada bio je da se utvrdi korelacija između sastava tela i specifičnih fizičkih sposobnosti, kao i da se utvrdi unakrsna korelacija između parametara sastava tela i specifičnih fizičkih sposobnosti. Za utvrđivanje veze između skupa prediktorskih varijabli i kriterijumske varijable korišćena je kanonička korelaciona analiza. Na osnovu dobijenih rezultata može se zaključiti da postoji značajna korelacija $(p=.010)$ između sastava tela i fizičkih sposobnosti. Može se zaključiti da višak masnog tkiva (BF\%, BFkg, indeks visceralni BF) i BMI negativno utiču na fizičke sposobnosti, dok veća količina mišićne mase (MM\% i MMkg) pozitivno utiče na iste. Rezultati pokazuju da učesnici koji nemaju toliko slojeva masti imaju bolje vrednosti za ponavljajuću snagu abdominalnih mišića $i$ da procenat mišićne mase pozitivno utiče na repetitivnu snagu pektoralnih mišića, mišića ruku i abdomena.

Ključne reči: sastav tela, specifične fitnes sposobnosti, oružane snage 